NEW YORK-Like most biotechnology companies, IG Laboratories (Framingham, MA) made some big promises when it went public in 1990 , raising $\$ 14.1$ million. The company-which is 70 percent owned by Genzyme (Cambridge, MA) vowed to evolve into no less than the top genetic-testing firm in the U.S. Key acquisitions and cutting-edge research, bragged IG Labs, would propel it to this lofty status.

Yet unlike most biotech companies, IG Labs kept its promise. The company currently controls about 15 percent of the $\$ 200$-million-a-year U.S. genetic-testing market, a market slated to reach $\$ 1$ billion by the late 1990s. Among the services making up this disparate market are fetal testing for genetic abnormalities, adult testing for genetic diseases, tissue typing for organ transplants and bone-marrow transplants, paternity testing, identity testing, and cancer testing. After IG Labs, the next biggest genetictesting players-Genetrix (Phoenix, AZ) and Medigene (Yonkers, NY) - each control about 5 percent of the market. The genetic-testing market is highly fragmented, with about 450 of the 500 laboratories offering such testing affiliated

\section{ES GENE}

with universities and hospitals. Of the 50 independent companies offering genetic testing, less than half offer services nationally.

\section{Turning a profit}

Several financial firms foresee IG Labs turning a profit next year. Vector Securities (Deerfield, IL) sees the company's 1991 sales of $\$ 9$ million tripling to $\$ 27$ million this year and then more than doubling to $\$ 61$ million in 1993. Sales should soar to $\$ 122$ million by 1996 , says Vector Securities.

\section{Key acquisitions \\ and cutting-edge}

research has made $I G$

\section{Labs tops.}

Without a doubt, acquisitions have played a major role in IG Labs's ascent. In 1990 and 1991, it built up a national service network by purchasing three regional genetic-testing laboratories, including Genetics Associates (Miami, FL), Odyssey Biomedical (W. Paterson, NJ), and Memorial Hospital's cytogenetics laboratory (Long Beach, CA). This year it purchased Genetic Design (Greensboro, NC) for $\$ 23$ million, a company with the biggest share, at 40 percent, of the U.S. paternitytesting market, as well as businesses in bonemarrow typing and identity testing. And this summer IG Labs acquired Vivigen (SantaFe, NM) for $\$ 40$ million. Aleading provider of fetal testing and cancer testing, Vivigen racked up profits of $\$ 1.2$ million last year on sales of $\$ 12.4$ million.

Technological developments have also contributed to IG Labs's ascent. Last year the company introduced a diagnostic test that cuts from two weeks to two days the time needed to analyze fetal cells for major chromosome
TESTING

abnormalities. The test, which bypasses fetal cell culturing, uses DNA probes to home in on regions of five chromosomes-including $21,18,13, \mathrm{X}$, and $\mathrm{Y}$ that together account for 95 percent of all birth defects related to abnormal chromosomes. Down's syndrome, for instance, is caused by an extra chromosome 21. The test, however, requires follow-up with traditional chromosome analysis to ensure detection of less common chromosome disorders.

\section{Cystic fibrosis test}

Later this year IG Labs plans to introduce a diagnostic test for cystic fibrosis (CF) that eliminates the need to draw patient blood. The DNA-based testwhich detects $12 \mathrm{CF}$ mutations and has an 84 percent detection rate-is performed on cells obtained by brushing the inside of a patient's cheek. For IG Labs, the $\$ 100$ test is a prototype for other DNA-based assays for single-gene disorders like sickle cell anemia and betathalassemia. "Given the cost and detection rate of the $\mathrm{CF}$ test, it might be considered as a broad screening and carrier test, not just as a prenatal test," says Elliott Hillback, IG Lab's president and chief executive officer.

For its part, the Congressional Office of Technology Assessment (OTA, Washington, DC) believes that the use of diagnostic tests to screen for CF carriers could become commonplace within the decade. OTA adds, moreover, that the "ongoing mission to map the human genome is likely to lead to at least a 10-fold increase in the number of tests for genetic diseases in the next decade."

To broaden fetal testing for genetic abnormalities, IGLabsis developing technology to separate fetal cells from a mother's blood. Such technology could replace the risky techniques currently used to collect fetal cells from pregnant women, including chorionic villi sampling (CVS) and amniocentesis. CVS has a spontaneous miscarriage rate of 1 percent to 2 percent, on average, while the miscarriage rate for amniocentesis is 0.5 percent. So these techniques are limited to pregnancies with high risks of fetal abnormalities, mostly those of women 35 and older, or 300,000 of the 3.8 million annual U.S. pregnancies.

"A non-invasive test would allow the screening of all pregnant women," says Jeffrey Casdin, an analyst at Oppenheimer (New York). "Ifabout half of pregnant women took the test, or about 2 million a year, and the test cost $\$ 250$, or half the price of existing tests, a new market of about $\$ 500$ milion a year would be created." -B.J. Spalding 